\title{
Aile ve Dini Rehberlik Bürosu Görevlilerinin Karşılaştıkları Psikososyal Sorunlara Yaklaşımlarının Dini Danışmanlık ve Rehberlik Açısından Değerlendirilmesi
}

\author{
Yasemin ANGIN**, Prof. Dr. Nurullah ALTAŞ ${ }^{* \star}$
}

Atıf / @-- Angın, Y. ve Altaş, N. (2018). Aile ve Dini Rehberlik Bürosu Görevlilerinin Karşılaştıkları Psikososyal Sorunlara Yaklaşımlarının Dini Danışmanlık ve Rehberlik Açısından Değerlendirilmesi, Çukurova Üniversitesi Illahiyat Fakültesi Dergisi, 18 (2), 661-689.

Öz- Bu araştırmada Diyanet Işsıeri Başkanlığı Aile ve Dini Rehberlik Bürolarına danışanlara yönelik yürütülen hizmetin içeriği, dini danışmanlık ve rehberlik zemininde ele alınmaktadır. Araştırmanın temel amacı, çeşitli boyutları olan sorunların getirildiği bu bürolarda gerçekleşen yardım ilişkilerini dini danışmanlık ve rehberlik açısından incelemektir. Bu araştırmada nitel araştırma modellerinden olan doküman inceleme yöntemi kullanılmıştır. Araştırmanın evrenini Türkiye genelinde bulunan ve Diyanet Iş̧leri Başkanlığına bağlı olan Aile ve Dini Rehberlik Bürolarına başvuran danışanlar ile onlara danışmanlık hizmeti sunan büro görevlileri oluşturmaktadır. Örneklem ise, konuşmaları yazılı materyale yansıyan büro personeli ve görüşme talebinde bulunan danışanlar arasından amaçsal örnekleme yöntemiyle belirlenmiştir. Araştırmaya kaynaklık eden veriler, ülke genelinde bulunan Aile ve Dini Rehberlik Bürolarına, 2014 yılının ilk 10 ayındaki başvuruların kaydedildiği 6857 karteksten ve kaynak taramasıly elde edilen dokümanlardan sağlanmıştır. Elde edilen veriler içeriğine göre analiz edilerek araştırmanın alt amaçları doğrultusunda kategorize edilmiştir. $\mathrm{Bu}$ verilerden seçilen bazı örnekler ise söz konusu yardım ilişkilerinin danışmanlık ilkelerine uygunluğu açısından yorumlanmıştır. Araştırmanın sonucunda Aile ve Dini Rehberlik Bürolarına başvuran danışanların, bir konunun dini hükmünü bilmek istedikleri için yardım isteğinde bulundukları ancak, çoğu kez psikolojik ve sosyal problemlerini de üstü kapalı veya açık olarak dile getirdikleri tespit edilmiştir. Yaşanan bu problemlerin ise mutsuzluk, çaresizlik, kararsızlık, suçluluk, değersizlik, bitkinlik, sosyal ortamlardan kaçınma gibi çeşitli yansımalarının

\footnotetext{
* Bu çalışma, Yasemin ANGIN tarafından Atatürk Üniversitesi Eğitim Bilimleri Enstitüsü'nde Prof. Dr. Nurullah ALTAŞ danışmanlığında yürütülen ve başlıkla tamamlanan yüksek lisans tezinden hazırlanmıştır.

** Atatürk Üniversitesi İlahiyat Fakültesi Din Psikolojisi Anabilim Dalı Doktora Öğrencisi eposta: naksiyeyasemin@gmail.com, ORCID: 0000-0002-9730-6027

*** Marmara Üniversitesi İlahiyat Fakültesi Din Eğitimi Anabilim Dalı eposta: nurullah.altas@marmara.edu.tr, ORCID: 0000-0003-4179-7645.
} 
olduğu görülmüştür. Bunun yanında büro görevlilerinin, ideal bir danışma süreci için gereken bilimsel ve sistemli altyapıya sahip olma konusunda yetersiz kalabildiklerini gösteren bulgulara ulaşılmıştır. Bu bulgular; büro görevlilerinin doğru bir danışmanlık ilişkisi için gereken koşulları sağlamada ve danışmanlık becerilerini sergilemede yetersiz kalabilmeleri, danışanların sorunlarını içgörü kazanarak ve etkin kararlar alarak çözmelerini sağlamada eksik rehberlik yapmaları, patolojik düzeyde sorunları olan danışanlarla yardım ilişkisi kurabilmek için gereken eğitime sahip olmamaları, danışanların aile ve evlilikle ilgili sorunlarını çözme noktasında gereken donanıma sahip olmamaları, diğer yardım meslekleriyle işbirliği ve yönlendirme ekseninde koordineli çalışabilecek eğitim ve deneyime sahip olmamaları şeklindedir.

Anahtar sözcükler- Aile ve Dini Rehberlik Bürosu, dini danışmanlık ve rehberlik, psikososyal sorunlar.

\section{$\S \S \S$}

\section{Giriş}

Din, insanları kutsal duygu, ortak bilinç ve vicdan etrafında birleştiren evrensel bir olgu olduğu gibi bireylere yön veren ve onları hem içten hem dıştan kuşatarak düşünce ve davranışlarda kendini gösteren bir disiplindir (Tümer, 1994, 317). İnanan insanlar dinin kendilerine sunduğu referanslar aracılığıyla hayatlarını kurmaya ve yaşam biçimlerini oluşturmaya çalışmaktadırlar. $\mathrm{Bu}$ açıdan din, bireyin yaşamsal alanında belirleyici bir özelliğe sahiptir.

Yaşamını dinin rehberliğinde düzene sokmak isteyen birey yalnızlık, çaresizlik, korku, kayıp ve yıkımlar karşısında da dini, umut ve güven aşılayan bir araç olarak görür ve kullandığı bir takım dini enstrümanlarla içinde bulunduğu sıkıntılı durumun üstesinden gelmeye çalışır. İnsanların dine yönelimlerinin dışavurumunu içeren dinsel pratikler ve zor zamanlarında sorunlarıyla baş ederken yerine getirdikleri dini uygulamalar, bireylerin psikososyal uyumlarına ve iyilik haline ulaşmalarına katkı sağlayan unsurlardır.

Gelişim dönemleri ve farklı yaşam çağları açısından bakıldığında, bireylerin gerek sözünü ettiğimiz dini uygulamalar ve bunlar aracılığıyla hayatı anlamlandırma konusunda, gerekse sorunlarını çözerken dini enstrümanları kullanma konusunda olsun, dini bir danışman ve rehber arama ihtiyacı 
Aile ve Dini Rehberlik Bürosu Görevlilerinin Karşılaştıkları Psikososyal Sorunlara Yaklaşımlarının Dini Danışmanlık ve Rehberlik Açısından Değerlendirilmesi | 663

duydukları gözlenmektedir (Şirin, 2014, 54). Tam da bu noktada "dini danışmanlık" şeklinde yeni bir kavram karşımıza çıkmaktadır. Batı'da "pastoral counseling" ismiyle 1900'lü yılların başında ortaya çıkan (Şirin, 2014, 33) bu kavram, yeni gelişmeye başlayan bir alanı tanımlamak üzere (Ege, 2011) Türkçe'ye geçmiştir.

Psikolojik yardım meslekleri arasında disiplinler arası bir konumu olan dini danışmanlık ve rehberliğin, teoloji ile davranış bilimlerini bir araya getirmesi ve fiziksel, zihinsel ve manevi yönü olan (Şirin, 2014, 35) bir yardım mesleği olması nedeniyle özgün bir alan oluşturduğu söylenebilir. Ülkemizde dini danışmanlık ve rehberliğin tam olarak ne olduğuyla, komşu disiplinler arasındaki konumuyla ve yöntemleriyle ilgili kavramsallaştırma çalışmaları devam etse de birçok araştırmacının dini danışmanlık ve rehberlik faaliyetleriyle ilgili, bireyin kendisiyle, ailesiyle, toplumla veya Tanrıyla olan ilişkilerinde psikolojik, sosyolojik ve teolojik yenileşmenin bir aracı olabileceğine dair görüşleri bulunmaktadır (Altaş, 2000; Cebeci, 2010; Koç, 2014, 72; Ok, 2012, 38-58).

Teorik olduğu kadar pratik boyutuyla da gelişmekte olan bu alan, ülkemizde Diyanet İşleri Başkanlığı Din Hizmetleri Genel Müdürlüğü çatısı altında, il ve ilçe müftülükleri bünyesinde açılmış olan Aile ve Dini Rehberlik Büroları aracılığıyla saha uygulamalarında kendini gösterme fırsatı bulmuştur. Böylece dini danışmanlık ve rehberliğe ilişkin akademik çalışmalarla paralel yürümesi gereken alan uygulamalarının önü açılmıştır. 2003 yılında beş ilimizde (Ankara, İstanbul, İzmir, Adana, Samsun ve Elazığ) kurulan bu bürolar, 2006 yılından itibaren ülke genelinde yaygınlaştırılmıştır.

Kuruluş amacının, halkın özellikle aile ve aile bireyleriyle ilgili dini içerikli soru ve sorunlarına çözüm üretmek olarak belirtildiği (Diyanet İşleri Başkanlığı[DïB], 2015a) bu bürolara, birçok kişinin rehber olarak gördüğü din görevlisinin görüş ve önerilerinden yararlanmak ve sorununun çözümüne katkı sağlamak amacıyla, danışmanlık hizmeti almak için başvurduğu bilinmektedir (Peker, 2012, 354). Bu durumda Aile ve Dini Rehberlik Büroları, dini 
danışmanlık ve rehberlik uygulamalarının yer aldığı önemli bir birim olarak faaliyet göstermektedir.

Bu bürolar toplumun intiyacını bir düzeye kadar karşılamaktadır. Ancak konu dini danışmanlık ve rehberlik olduğunda söz konusu hizmetin uzmanlık gerektiren bilgi ve becerilere sahip personel tarafından yerine getirilmesi gereken bir alan olduğu kabul edilmelidir. Bu noktada adı geçen bürolarda gerçekleşen danışmanlık faaliyetlerinin niteliği araştırılmaya değer görülmektedir. Danışanların bürolara getirdiği sorular incelendiğinde, bu soruların bazı psikososyal sorunları da barındırdığı gözden kaçmamaktadır. Zira bireylerin din ile ilişkilendirdiği her türlü sosyal, psikolojik ve fiziksel sorunu danışma ortamına getirebildikleri gözlenmektedir (Ege, 2015, 106-125; Ş. Özdemir, 2007, 119). Bu da, dini referanslarla problemini çözmek isteyen danışanların, danışmanlık eğitimi almış dini danışmanlarla karşılaşması gerektiğinin önemini ortaya koymaktadır.

Her ne kadar DİB bu bürolarda çalışan personele yönelik olarak, sosyal konularda farkındalığı ve duyarlığı arttırmak gayesiyle eğitim seminerleri, koordinasyon toplantıları gibi farklı etkinlikler düzenlese de (DİB, 2015b) bürolardaki uygulamalar dikkatli bir şekilde incelendiğinde, danışanların dinî içerikli sorunları için informel olan bir dinî danışmanlık ve rehberlik hizmeti sunulmaya çalışıldığı izlenimi oluşmaktadır (Söylev, 2015).

$\mathrm{Bu}$ çerçevede, Aile ve Dini Rehberlik Bürolarına müracaat eden bireylere sunulan hizmeti, danışmanlık ilkeleri temelinde inceleyerek yapılacak bir değerlendirmeye intiyaç duyulduğu anlaşılmaktadır. İşte bu araştırma, Aile ve Dini Rehberlik Bürolarında gerçekleşen yardım ilişkilerini dini danışmanlık ve rehberlik açısından incelemek amacıyla yapılmıştır. Alt amaçlar ise,

1. Aile ve Dini Rehberlik Bürolarına getirilen soru ve sorunlar, dini boyut dışında başka hangi boyutları içermektedir?

2. Farklı boyutları olan sorunlarla karşılaşan büro görevlileri verimli ve işlevsel bir danışma oluşumu sağlamada yeterli donanıma sahip midir? 
Aile ve Dini Rehberlik Bürosu Görevlilerinin Karşılaştıkları Psikososyal Sorunlara Yaklaşımlarının Dini Danışmanlık ve Rehberlik Açısından Değerlendirilmesi | 665

3. Büro personelinin yetiştirilmesi amacıyla Diyanet İşleri Başkanlığı tarafından organize edilen eğitim programları, bu görevlilerin danışanların sorunlarıyla ilgili farklı boyutları görebilme ve danışma sürecini doğru yönetebilme gibi bazı temel kazanımları elde etmesini sağlayabilecek kapsamda mıdır? sorularına cevap bulmaktır.

Doküman inceleme yönteminin kullanıldığı bu çalışmanın verileri, 2014 yılının ilk 10 ayında Aile ve Dini Rehberlik Bürolarına yapılan başvuruların kaydedildiği 6857 karteks ve kaynak taramasıyla elde edilen dokümanlardan sağlamıştır. Bu veriler içeriğine göre analiz edilmiş ve araştırmanın alt amaçları doğrultusunda kategoriler belirlenmiştir. Yapılan kategorizasyona giren verilerden seçilen bazı örnekler ise söz konusu yardım ilişkilerinin danışmanlık ilkelerine uygunluğu açısından yorumlanmış, bu sırada görüşmelerin içerdiği konuşmaların anlam değişikliğine uğratılmadan verilmesine özen gösterilmiştir.

\section{Aile ve Dini Rehberlik Bürolarına Danışanların Sorunları}

Aile ve Dini Rehberlik Bürolarına yapılan başvuruların olduğu veri grubu incelenerek genel bir değerlendirme yapıldığında; büro görevlileriyle paylaşılan konuların yer aldığı "aile büro karteks listesinin" 5 ana konu (fıkhi sorular, sağlık, aile, sosyal durumlar, evlilik-boşanma-nikah) etrafında şekillendiği görülmektedir. Aile Büro Karteks Listesi incelendiğinde danışanların, çoğunlukla yüz yüze veya telefonla başvurularını gerçekleştirdiği anlaşılmaktadır. Dile getirilen sorunların yoğunlaştığı alanlar göz önünde bulundurulduğunda, ilk sırayı \%45,7 ile "fıkhi sorular" almaktadır. Onu takiben \%25,7 ile "evlilik-boşanma-nikah" ve sırasıyla; \%20,3 ile "aile", \%4,2 ile "sosyal durumlar", \%4,1 ile "sağlık" gelmektedir. Ayrıca toplamda yöneltilen 6857 sorunun 246'sı büro görevlilerince çeşitli kurumlara (ASPB İ Müdürlükleri, ŞÖNIM, ATM, Emniyet, ÇìM ve barolar) yönlendirilmiş olduğu görülmektedir. Diğer kurum ve kuruluşlara yapılan yönlendirmeler $\% 3,5$ oranındadır.

Aile ve Dini Rehberlik Bürolarına danışan bireylerin sordukları sorular içerik olarak incelendiğinde, bunlar arasında tek cümlelik, yalnızca fetva isteyen sorular olduğu kadar, bireyin ekonomik, fiziksel, psikolojik ve sosyal 
problemlerini içeren soruların da olduğu anlaşılmaktadır. Birey dini hassasiyetinin olduğunu belirterek sorusunu yöneltirken, uzun uzun içini dökebilmekte ve mutsuzluk, çaresizlik, suçluluk, değersizlik, kararsızlık, bitkinlik, sosyal ortamlardan kaçınma gibi yaşadığı çeşitli problemleri dile getirebilmektedir.

Ülkemiz insanlarının genel olarak, birincil önleme nedeniyle ya da durumsal veya gelişimsel konularda çözüm bulmak için psikolojik danışma hizmeti almaya yeltenmediği, stres altına girene ve bunalana kadar bunu ertelediği düşünülmektedir. Aynı şekilde, söz konusu bürolara danışan bireylerin çoğunun dini bilgi eksikliği bir takım yaşamsal çıkmazlara neden olduğunda, kendilerine yardım sağlayabilecek bir rehber arayışına girdiği görülmektedir. Yönelttikleri dini soruların ise bireyin duyuşsal, bilişsel, fiziksel ve davranışsal tarafıyla iç içe geçmiş diğer sorunların da ortaya çıkmasına sebep olduğu fark edilmektedir. Bu da bireyin, sorunlarını ilk paylaştığı kişinin büro personeli olması sonucunu doğurabilmektedir. Aşağıdaki örnekler bu durumun varlığını göstermektedir:

"Ben takıntı hastasıyım. IIImihalden boşanma bölümlerini okudum, kafam karıştı. Ne yapmalıyım?”

"Temizlik hastasıyım. Çocuklarıma devamlı el yıkatıyorum, kendim hiç mutlu değilim. Eşimle beraber olmak istemiyorum. Zira gusül beni çok yoruyor. Dışarıda erkek görsem eve gelip banyo yapıyorum. Namaz abdesti ve gusül olmadı diye çok tekrarlıyorum, ne yapmalıyım?"

"4-5 yaşlarında iken cinsel tacize maruz kaldım ve çocukluktan kaynaklanan bilgisizlikle bekaretimi kaybettiğim konusunda endişelerim oldu. Fakat 10 ya da 16 yaşlarında iken (yaşımı tam hatırlamıyorum) ben de yakınlarımın çocuklarını kucağımda tutmaktan zevk aldım. Yakın zamana kadar bunun günah olabileceğini düşünmemiştim. Şimdi çok üzgünüm. Bu günahı nasıl telafi edebilirim, onlar ahirette haklarını isterlerse ne yapacağım?"

Bazen büroya başvuran kişi, içinde bulunduğu sistemin (aile/sülale/toplum) bir parçası olarak dini hassasiyetleri korumak isteyen ve aynı zamanda duygu karmaşası yaşayan biri olabilmektedir. 
Aile ve Dini Rehberlik Bürosu Görevlilerinin Karşılaştıkları Psikososyal Sorunlara Yaklaşımlarının Dini Danışmanlık ve Rehberlik Açısından Değerlendirilmesi | 667

“Geçen yıl YGS öncesi babamı kaybettim. Bu da sınavım üzerinde olumsuz bir etki oluşturdu. Üç yıldır görüştügümm erkek arkadaşım gitti başkasıyla evlendi. Annem bana baskı uyguluyor ve hiçbir yere göndermiyor. Bense buralardan gitmek, başka şehirde okumak istiyorum. Rahmetli babamı sürekli rüyamda görüyorum. Akrabalarım bunun bana örtünmem için bir işaret olduğunu söylüyor. Gerçekten öyle mi? Sürekli kabuslar görüyorum. Bu da bana bir işaret mi? Başıma hep talihsizlikler geliyor. Bende bir uğursuzluk mu var? Büyük bir günah işledim de o yüzden mi bunlar başıma geliyor?”

Bütün bu örneklerde, danışanın kendisine yardım edebileceğine inandığı büro görevlisinin önünde, dini ve psikolojik boyutlarıyla karmaşık hale gelmiş bir tablonun var olduğundan söz etmek mümkündür.

Başka bir örnek: "Sekiz yıllık evliyim. Gazeteci idim. Bipolar hastasıyım. Dindar bir insanım, namazımı kılarım. Yakın bir zamana kadar örtülü idim. Eşimin hiçbir dini hassasiyeti yok. Başta birbirimizi çok seviyorduk. O zaman eşim çevresini değiştirmek istiyordu ama bu mümkün olmadı. Rahatsızlıklarımın arttığı bir dönemde çok ciddi tedavi görmem gerekti. Bu arada eşim arkadaş çevresinde uyuşturucu kullanmaya devam etti. Bizim anlaşmazlıklarımız da had safhaya geldi. Eşim beni iki defa ayrı zamanlarda boşadı. Şimdi ayrılmak için mahkemeye başvurdu ve altı aydır ayrı yaşıyoruz. Ben eşimden ayrılmak istemiyorum. Ne yapabilirim?"

Bu örnekte danışanın tek bir soru yöneltmekten çok içinde bulunduğu sıkıntılı durumu detaylarıyla paylaştığını görüyoruz. Öncelikle şunu belirtmek gerekir ki, bu kişiyi sadece dinlemek bile profesyonellik isteyen bir iştir. Danışanın sorusuna gelince; boşanmanın gerçekleşip gerçekleşmediğini belirleyen dini hükmü, yaşanan psikiyatrik hastalığı ve belki hastalığın getirdiği psikolojik travmayı, zamanla değişen dini tutumu, yaşanan çaresizliği, aile işlevselliğini engelleyen durumları ve daha fazlasını göz önünde bulundurmayı gerektirecek kadar çeşitlilik içeren bir soruyla karşılaşmaktayız.

Benzer biçimlerde, dini içerikli sorularla yaşanan psikososyal sorunların bir araya geldiği daha pek çok örnek verilebilir. Burada üzerinde durulması 
gereken konu, dini hassasiyeti olduğunu vurgulayan danışanın, yönelttiği sorunun içinde birçok problemin barınması ve bunların birbirleriyle ilintili olmasıdır.

“Hocam eşimle sürekli kavga ediyoruz. Ben altmış yaşında bir bayanım, eşim de yetmiş yaşında. Yaşımız ilerledikçe olgunlaşmamız gerekirken kavgalarımız daha da artmaya başladı. Íkimiz de dinine bağlı, ibadetlerini yerine getirmeye çalışan insanlarız. Eşim bana karşı kaba ve kırıcı davranınca ben de ona karşı geliyorum. Bu halimden rahatsız oluyorum, huzurum bozuluyor. Bu durumdan ben hoşnut değilim, psikolojim bozuldu. Bu da sağlık problemlerimin artmasına neden oldu. Bu durumu çocuklarıma da yansıtamıyorum. Onlar bizden ayrı, hepsi de evli insanlar. Babalarını da çok seviyorlar, onu çok iyi bir insan olarak görüyorlar. Kimsenin huzurunu da bozmak istemiyorum. Bu durumda ne yapacağımı bilemediğim gibi katlanacak gücüm de kalmadı. Siz bana bu konuda yardımcı olabilir misiniz?”

Bu ve benzeri sorular, dindarlık düzeyleri değişse de dine yakınlığı olan danışanların, danışmanlık eğitimi almış dini danışmanlarla karşılaşması gerektiğinin önemini ortaya koymaktadır. Bu bağlamda, bürolara başvuran kişiler için kullanılan "danışan” kelimesinin özellikle seçildiğini belirtmek isteriz. Çünkü kurulan ilişki, "danışman” ve "danışan” öğelerini içeren bir danışma ilişkisidir.

Aile ve Dini Rehberlik Bürolarına başvuran danışanların soruları kritik edildiğinde; ebeveyni, kayınvalidesi veya geliniyle çatışma yaşayan bireylerin, çocuk yetiştirme konusunda sorunları olan anne-babaların, eşiyle anlaşmazlıkları olanların, şiddete uğrayan kişilerin, alkolik eşe veya çocuğa sahip olanların, tacize uğrayan kadınların, uyuşturucu bağımlısı yakını olan bireylerin, ensest ilişki kurbanı veya uygulayıcısı olan yetişkinlerin, psikiyatrik tedavi gördüğü halde çaresizce yardım isteyenlerin ve benzerlerinin hep dini boyutunu öğrenmek istedikleri bir konuyu büroya getirdikleri ama yakınmalarının daha fazla olduğu tespit edilmiştir. 
Suçluluk duygusu söz edilen yakınmalardan sadece biridir. Özellikle geçmişte işlediği günahlardan dolayı pişmanlık duyan ve Allah'ın kendisini affetmeyeceği endişesini taşıyan bireylerin yoğun olarak yardım istediklerini görebiliyoruz. Bu noktada danışanın, yaşadığı sorundan kurtularak rahatlamak istediğini ve bunu yaparken de "dini" yardım kaynağı olarak kullanmayı seçtiğini söyleyebiliriz. Bazı danışanların “....yaparsam günah olur mu?”, "onu günaha ben mi sokmuş oldum?" ya da "şimdi Allah beni affeder mi?" şeklindeki ifadeleri bu anlamda dikkat çekicidir.

Dikkat çekmesi gereken diğer bir konu, başvuru sahibinin kendisiyle ve yaşadığı çevreyle ilgili sorunlarını çözmek için bir din görevlisine gelmeyi tercih etmesidir. Çünkü danışan, dinin kendisine göstereceği yolu otomatik olarak kabul etme eğilimindedir. Öyle ki din; ahlaki, duygusal ve estetik tüm boyutlarıyla yaşamını şekillendirmesine izin verdiği bir kaynaktır. Şu durumda bir din görevlisi olan büro personelinin sunacağı yardımın, danışanın hayatında düzenleyici ve toparlayıcı bir işlevi olmalıdır.

Bu noktada şunu vurgulamak yerinde olacaktır; bir dini danışman danışanın getirdiği konuyla ilgili dini hükmü bilmekle birlikte, danışanın yaşam becerileri kazanmasında olumlu destek sağlamayı da amaçlar. En önemlisi, bunu yaparken "üç kişi psikolojisinden" yararlanır. Sayar $(2014,177)$ psikanalizin "tek kişi psikolojisi", insanı sosyal bağlamından ayrı düşünmeyen ilişkisel terapilerin "iki kişi psikolojisi", üçüncü oyuncu olarak tarih, kültür, politikanın oluşturduğu sosyal alanların devreye girdiği terapilerin "üç kişi psikolojisi" olduğunu söyler ve psikoterapiyi daha kuşatıcı hale getirebilecek üç kişi psikolojisinin önemine değinir. Burada üçüncü oyuncu olarak, kültürün dokusunu oluşturan en öncelikli unsurun din olduğunu söyleyebiliriz. Dolayısıyla insanımıza ait din eksenli değerleri, incelik ve hassasiyeti hesaba katarak uygulanacak bir terapi, danışanlara yaşam taktiği vermekten öte onların hayatına derin bir anlam katacaktır.

Aile ve Dini Rehberlik Bürolarına Danışanlara Gösterilen Yaklaşım 
Diyanet İşleri Başkanlığı, din hizmetlerindeki sorunların belirlenerek çözüm önerilerinin tartışıması, kullanılan yöntemlerin geliştirilip güncelleştirilmesi amacıyla şura, seminer, kongre, çalıştay ve istişare toplantıları düzenlemekte ve bu bağlamada Aile ve Dini Rehberlik Bürolarında çalışan personele yönelik eğitim seminerleri, koordinasyon toplantıları gibi etkinlikler gerçekleştirmektedir. Daha verimli bir din hizmetinin amaçlandığı bu etkinlikler olumlu gelişmeler olmakla beraber, Dỉ'in birtakım gerekçelerle belirlediği çeşitli yeterlikleri, hizmet içi eğitim ve seminer düzenleme yoluyla kazandırma çabası yetersiz görülmekte, bazı özel yeterliklerin ancak akademik bir öğretimle kazandırılabileceği dile getirilmektedir (Aşıkoğlu, 2012, 225). Ayrıca Aile ve Dini Rehberlik Bürolarındaki görevlilere yönelik düzenlenen seminerlere katılan bazı görevliler tarafından, seminerlerin yararlı olduğu ancak yeterli olmadığı dile getirilmekte ve danışanların sorunlarından hareketle nasıl bir süreç izlenmesi gerektiği üzerinde durulmasının daha yararlı olacağı belirtilmektedir (Peker, 2012, 355).

Bu çerçevede, Aile ve Dini Rehberlik Bürolarına müracaat eden bireylere gösterilen yaklaşımı ele alarak yapacağımız değerlendirme, söz konusu bürolarda gerçekleşen görüşmelerin niteliğini -danışmanlık ilkeleri açısından- tartışarak, sunulan hizmete katkı sağlama amacını gütmektedir.

Aile ve Dini Rehberlik Bürolarında yürütülen dini danışmanlık ve rehberlik hizmetlerinin, din tabanlı birtakım yöntemleri, teknikleri ve karşılaşılan olayların karakterine uygun olarak bunların farklı kullanımlarının olması kaçınılmazdır. Doğru ve etkili hizmet üretebilmenin gereklerinden biri de kişiler arası ilişkilere dair kuralların olmasıdır. Bununla ilgili olarak kazanımların amaçlandığı aktivitelerde, kuramsal anlamda birçok konu işlenmektedir. Ancak fazlaca teorik bilgiye sahip olmak, bunların uygulama alanında kullanılabilmesini bireye sağlayamayabilir. Söz gelimi, birçok yerde empatinin (duygudaşlık) iletişimdeki önemli rolü üzerinde durulmakta ve "empatik olun" vurgusu yapılmaktadır. Ancak bunun pratikte nasıl yapılacağı öğretilmemektedir. Elbette büro görevlisi, bir insan olarak, karşılaştığı olayları kendi referans açısından değerlendirmeye daha çok alışıktır. Danışmanlık 
Aile ve Dini Rehberlik Bürosu Görevlilerinin Karşılaştıkları Psikososyal Sorunlara Yaklaşımlarının Dini Danışmanlık ve Rehberlik Açısından Değerlendirilmesi | 671

ilişkisinde ise bu alışkanlıktan sıyrılıp, danışanın referans açısından bakabilmelidir. Konuyla ilgili daha sağlıklı değerlendirme yapabilmek için büro görevlilerinin, karşılaştıkları dini içerikli psikososyal sorunlara yaklaşımlarını belli başlıklar altında incelemek yerinde olacaktır.

\section{Büro Görevlilerinin Danışanı Anlamaya Yönelik Geliştirdikleri Tutum:}

Doğru bir danışma ilişkisi, dini danışman rolünü üstlenen büro görevlisinin danışanla etkili bir biçimde iletişim kurabilme becerisine bağlıdır. Bu da öncelikle danışanı etkin ve kontrollü bir biçimde dinleyebilmeyi gerektirir. Öyle ki danışman konuşanın yüzüne bakarak göz teması kurar, danışanın kendini açması ve onu doğru anlayabilmek için sorular sorar, önemli bölümleri ve duyguları tekrar eder, danışanın sözünü kesmez ve kendi problemlerinden bahsetmez (Ergül, 2008). Kısacası istenen yardım ilişkisinin kurulabilmesi danışanı gerçekten dinlemek ve anlamakla yakından ilgilidir. Aile ve Dini Rehberlik Bürolarında yapılan görüşmelere bakıldığında her zaman olmasa bile bazen konuyla ilgili hatalı yaklaşımların olduğu görülmektedir.

Örnek vermek gerekirse, Aile ve Dini Rehberlik Bürosuna başvuruda bulunan bir danışan, eşi ile anlaşmazlık yaşaması sebebiyle evini terk etmek istediğini belirtmiş, büro görevlisi de bu isteğin altında yatan sebepleri anlamaya çalışmak yerine, "akılı kadın evini terk etmez" şeklinde cevap vermiştir. Başka bir danışan, eşinin kendisine yeterli harçlık vermediğinden ve intiyaçlarını karşılayamadığından yakınmıştır. Bu kişiye büro görevlisi, "Kardeşim, erkekler de tutumlu olmasa biz kadınlar savurur gideriz. Ne evimiz olur ne de arabamız." diyerek şiddet içeren daha kötü olayların varlığından bahsetmiş, haline şükretmesini tavsiye etmiştir (DỉB, 2009, 9). Buna benzer örnekleri çoğaltmak mümkündür. İyi niyetle de olsa verilen tavsiyeler, karşı tarafın ihtiyaçlarını gidermekten uzak veya hayattan kopuk olduğunda, yararlı olmadığı gibi danışma ilişkisine zarar da verebilir. Burada öncelikle danışanla empati kurarak, onun ilk olarak neye gereksinim duyduğunu görmek, onu anlamak önemlidir. 
Inncelenen kartekslerde danışanların öncelikle, kendilerinde gerginlik yaratan, problemlerini objektif bir şekilde görüp anlamalarını engelleyen, onlara acı ve ağırlık veren duygu ve düşüncelerini anlatarak hafiflemek istedikleri anlaşılmaktadır. Bu gereksinimi karşılamak, danışmada katarsis ya da deşarj diye adlandırılan ve danışanın katı savunma mekanizmasını gevşeten geçici bir amaçtır (Tan, 1992, 86). Bu durum karşısında, büro görevlisinin danışanın sadece sözel ifadelerine değil, ses tonuna, konuşma temposuna, jest ve mimiklerine, duruşuna dikkat etmesi; dile getirilen duygunun şiddetine uygun tepki vererek empati kurması beklenir (Voltan Acar, 2014, 24). Bu ise danışanın anlam dünyasının inceliğine vararak, sadece danışanın farkında olduğu anlamları değil onun farkındalık düzeyinin altındaki anlamları da ortaya koyabilmekle ilgilidir (Hackney ve Cormier, 2008,47).

Büro danışmanının, danışanın farkındalık düzeyinin altındaki anlamları, davranış ve düşüncelerinin gerisinde olan duyguları ortaya çıkarması, onu konuşturabilme becerisine de bağlıdır. Danışman yerinde ve zamanında gösterdiği davranımlarla, danışanın daha çok konuşarak kendini açmasını ve anlatmasını sağlamalıdır. Böylece hem danışmanın danışanın dünyasından bakarak onu anlaması, hem de danışanın kendini aktif olarak görmesi sağlanacaktır. Bu ilişkide konuşmanın çoğunu danışan yapmalı, danışman ise açık ve somut karşııılar vererek, danışanın ilgisiz detayların kalabalığından kurtulmasını ve asıl önemli unsurları görmesini sağlamalıdır (Tan, 1992,108-136).

Danışanı konuşturabilmek, ona açık uçlu sorular sorarak veya bu soruların yerine geçebilecek ifadeler kullanarak mümkün olmaktadır. Açık uçlu sorular danışanın, onu kaygılandıran şeylere ve onu rahatsız eden duygu veya düşüncelere odaklanmasını sağlayarak, sorunlarının su yüzüne çıkmasına neden olur. Danışman bu soruları kendi merakını gidermek için değil, danışanın belli bir noktaya odaklanmasını veya belirli davranış örneklerinin ortaya çıkmasını sağlamak için sormalıdır. Bu sayede danışanın getirdiği konuları çevreleyen ayrıntıları anlamak mümkün olacaktır (Voltan Acar, 2014,5-6). 
Açık uçlu soruları örneklendirmek gerekirse; "Şaşkınım derken neyi kastettin?", "O sana bu tür şeyler söylediğinde nasıl hissediyorsun?", "Bunu, ondan istemeni engelleyen nedir?" gibi kısa bir cevaptan daha fazlasını isteyen sorular gösterilebilir. "Çok kederlisin, değil mi?", "Kocanla mı yoksa oğlunla mı sorunların var?" gibi sorular da kısa cevap isteyen ve konuşmayı boğduğu için danışmada sıklıkla kullanılması önerilmeyen kapalı uçlu sorulara örnek olarak gösterilebilir. Öte yandan "niçin?" sorusu da kaçınılması gereken bir soru tipidir. Çünkü kişiyi yanıt vermeye zorlayan, yargılayıcı bir sorudur ve bu yönüyle, danışanın savunmaya ya da saldırıya geçme olasıığını barındııı (Tan, 1992, 173).

Aşağıdaki örnek diyalog, danışanı konuştururken açık uçlu sorulardan nasıl faydalanılacağını somutlaştırmak için verilmiştir.

Danışan: Ben hayatıma giren insanlara çok fazla değer veriyorum, zaman zaman da sıkıntı yaşıyorum, çünkü değer verdiğim insanları hayatımın merkezine alıyorum.

Danışman: Şimdiye kadar değer verdiğin ve yaşamının merkezine aldığın kimler var?

Danışan: Ailem var tabii de onları ayrı tutarsam arkadaşlarım. Yapı olarak çabuk alışan bir yapım var. Mesela çok hayvan besledim ve hepsi de bir yıkımdı benim için. Ölen hayvanlarıma bile çok fazla üzülüyordum, insanlar çok saçma buluyorlardı. Ben öyle değilim. Her şeye çok çabuk alışıyorum, olaylara bile. Bir canlıyı bırakın, hayatımdaki olaylara bile.

Danışman: Olay derken neyi kastediyorsun?

Danışan: Mesela bir ortamım var, o ortama çok alışıyorum. 0 ortamdan çıktıktan sonra o beni çok üzüyor.

Danışman: Şimdiye kadar hangi ortamdan ayrıldığın için üzüldün? Danışan: Mesela lise boyunca çalışıım, tatillerde. Hediyelik eşya satan bir dükkanda çalışıyordum. Çalışıı̆ım ortam çok iyiydi, sonra sıkıntı yaşadıkları için dükkanı kapattılar. $O$ ortamdan 
ayrıldığım için çok üzüldüm. Sonra bir daha olmadı, o ortamı yakalayamadım ama aklımda hep yeri vardır.

Danışman: O ortamdaki işin bitmesi senin için ne anlama geliyor? Danışan: O ortamdan uzaklaşmak demek. Ben iş olarak görmüyordum, ilgim olan şeylerdi. İlgim olan şeylerle ilgili kendimi geliştirme imkanım da vardı.

Danışman: Kendini geliştirmek, başka?

Danışan: Başka... Erken yaşta başladığım için gerçekten kendi ayaklarım üzerinde durduğumu hissedebilmiştim. Büyüdüğümü hissetmiştim.

Danışman: Kendi yaşının üstünde bir potansiyel ortaya koydun.

Bunun sonucunda nasıl bir duygu yaşıyorsun?

Danışan: Kendine güven duygusu.

...(Voltan Acar, 2012, 179-180).

Bu diyalogda danışman, doğru sorularla danışanı konuşmaya davet etmiş ve danışanın, yaşadığı duyguyu bulmasına yardımcı olmuştur.

Danışan konuştukça duygu ve düşüncelerini tanımaya, incelemeye ve dillendirmeye alışır. Davranışlarının altında duygularının yattığını, yaşantılarına anlamı, bu subjektif duyguların verdiğini görür. $\mathrm{Bu}$ ise danışanın, davranışlarının altında yatan asıl motivleri anlamasını sağlar ve onun daha realist kararlar alıp davranışlarını şekillendirmesinde etkili olur (Tan, 1992, 158).

Yukarıda değindiğimiz "evini terk etmek isteyen kadın” örneğinden yola çıktığımızda, bu danışanın böyle bir isteğinin olmasının altında, ilk bakışta hemen anlaşılamayabilecek başka sebeplerin yatması muhtemeldir. Aile ve Dini Rehberlik Bürolarına getirilen diğer sorunları da düşündüğümüzde, büro görevlisinin, danışanın davranışlarının ve düşüncelerinin altında yatan duyguları tam olarak anlamaya çalışıp problemin çeşitli boyutlarını görmeden sağlıklı bir danışmanlık ilişkisi sürdürmesinin çok zor olacağı kanaati uyanmaktadır. 
Aile ve Dini Rehberlik Bürosu Görevlilerinin Karşılaştıkları Psikososyal Sorunlara Yaklaşımlarının Dini Danışmanlık ve Rehberlik Açısından Değerlendirilmesi | 675

\section{Büro Görevlilerinin Danışanın Sorununu Çözmeye Yönelik Geliştirdikleri Tutum:}

Danışma ilişkisinde amaç, danışanın olup bitenleri daha iyi hissetmesine, tanımasına, düşünmesine, analiz etmesine, karar vermesine ve onun gelişmesine yardımcı olmaktır. Bu da danışanın kendini anlatarak yaşantılarını anlaması, değerlendirmesi ve öğrenmesiyle gerçekleşebilir. Danışman yerinde ve zamanında gösterdiği davranımlarla, danışanın konuşarak kendini açmasını, anlatmasını, aktif olarak kendini görmesini ve dinamik kararlar almasını sağlamalıdır (Tan, 1992, 108-136). Bürolarda yaşanan deneyimlere baktığımızda ise büro görevlilerinin bir kısmının, birkaç cümlelik tavsiyelerle yüzeysel bir çözüm bulma davranışı içinde olduklarını anlıyoruz. Burada dikkat çekmek istediğimiz konu verilen tavsiyelerin doğruluk veya yanıışlığı değil, intiyacı karşılamada yetersiz kalmasıdır.

Büro kartekslerine yansıyan cevaplarda yer alan bazı ifadeler incelendiğinde sözünü ettiğimiz durumun varlığı kendini göstermektedir. Eşinin evde kendisiyle ilgilenmediğini, hakaret ettiğini, eşinin ailesiyle problemler yaşadığını ve çocuklarını alıp evi terk etmeyi düşündüğünü söyleyen bir kadın danışana büro görevlisinin, "sana düşen onu olduğu gibi kabul etmendir" şeklindeki ifadesi, yine bir danışanın eşinin geçmişte yaptıklarını sürekli sayıp döktüğünü ve ondan öç almak istediğini, hatta patlayacak duruma geldiğini söylemesi üzerine büro görevlisinin "bunları durmadan irdeleyerek kendi huzurunuzu ve ailenizin huzurunu bozmayın" şeklindeki tavsiyesi, danışanın sorunuyla ilgili içgörü kazanarak etkin kararlar alma davranışını geliştirmesi için rehberlik etmekten çok, kısa yoldan çözüm bulma çabası olarak anlaşılmaktadır. Halbuki bu sorunlar derinlemesine ele alınmayı gerektiren yapıdadır ve bu yönüyle sistemli bir dini danışmanlık sürecine intiyaç duymaktadır.

Başka bir örnekte yine bir kadın danışan büro görevlisine, kocasını iki ayrı kişi ile aldattığından, daha sonra bu kişilerin kendisinden uzaklaştıklarından, şimdi büyük bir pişmanlık yaşadığından ve kendini 
kullanılmış hissettiğinden bahsederek ne yapabileceğini sormuştur. Büro karteksine yansıyan cevapta ise görevlinin danışana, bu kişilerle görüşmeyi kesmesini ve derhal tövbe etmesini söylediğini görüyoruz.

Burada son örnekteki sorun ve büro görevlisinin verdiği cevap üzerinden sunulan hizmetin kritiğini yapmaya çalışıp konuyu aydınlatmayı umuyoruz.

Öncelikle, söz konusu görüşme şeklinin telefonla olması büro görevlisini kısıtlamaktadır. Bu durumda danışmanlık süreci devam edemeyecek, istenen yardım sağlanamayacaktır. Bu noktada; dış müdahalelerin olmadığı, rahatsız edici gürültü ve görüntülerden uzak, danışan ve danışmanın kullanabileceği bir görüşme odasının gerekliliği ortaya çıkmaktadır. Ancak bu şekilde, açıklanan duygu ve düşüncelerin gizli kalacağı güvencesi sağlanabilir ve danışmanlık için doğru zemin oluşturulabilir.

Danışmada yardım etkileşiminin amacı, danışanın kendini ve etrafında olup bitenleri tanıma, düşünme, öğrenme, eleştirme, değerlendirme, karar verme ve değişip gelişmeyi isteme gücünü arttırmaktır (Tan, 1992, 136). Dini danışman, gösterdiği dostane yaklaşımla, yerinde ve zamanında kullandığı tekniklerle danışanı bu amaca götürmelidir. Ortak bir sorumluluğun paylaşıldığı bu ilişkide danışmanın danışan adına karar vermesi doğru değildir. Nitekim Kur'an-ı Kerim'de ""Ona (kötülüğün ve iyiliğin) iki yolunu da göstermedik mi?" (Beled, 90/10), "Biz ona doğru yolu gösterdik. Şükredici ya da nankör (olması artık kendisine kalmıştır)." (İnsan, 76/3) buyurulmakta ve yaptığı davranış nedeniyle sorumluluğun bireye ait olduğu vurgulanmaktadır. Buna göre danışanın, kendi varoluşundan sorumlu bir öğe olarak etkin kararlar vermesi sağlanmalıdır.

Verilen örnekte büro görevlisinin "bu kişilerle görüşmeyi kes ve derhal tövbe et" tavsiyesi ile danışan adına kendisinin karar verdiği anlaşılmaktadır. $\mathrm{Bu}$ da danışanın, içgörü geliştirerek kendini gerçekçi bir şekilde değerlendirip eleştirmesine fırsat vermemektedir. Aslında bu danışanın, sorununu bir din görevlisiyle paylaşması problemini dinin temel referanslarıyla çözmek istediği 
Aile ve Dini Rehberlik Bürosu Görevlilerinin Karşılaştıkları Psikososyal Sorunlara Yaklaşımlarının Dini Danışmanlık ve Rehberlik Açısından Değerlendirilmesi | 677

anlamına gelmektedir ancak, danışma ilişkisinde kullanılan yöntem bu olmamalıdır. Diğer birçok örnekte de benzer bir tutumla büro görevlilerinin, salt soruları cevaplama işine odaklanarak acele ettikleri ve çözüm dayatma davranışı içine girdikleri belirlenmiştir (Karacoşkun, 2007). Bir dini danışman danışanını aktif dinleyerek, sözlerin altında yatan duygu ve düşünceleri anlamaya çalışmalıdır. Bunun için sorunu bir an önce çözmeye çalışmak yerine, problem ne kadar aykırı olursa olsun, onun sözlerini ve duygularını istediği gibi ifade etmesine olanak tanımalıdır. Yine bir dini danışman, her konuda bir fikri olup verdiği tavsiyelerle danışanın ihtiyaçlarını bir çırpıda halletmeye çalışan değil, danışanı anlamaya çalışıp onun kendi kendisine yeni bir yol çizmesine yardım eden ve bu süreçte ona destek olan kişi olmalıdır (Karagül, 2012).

Üzerinde durduğumuz örnekte danışanın, bahsettiği kişilerle olan ilişkisini bitirip bitirmediği konusunda soru işaretleri vardır. Ayrıca kendini kullanılmış hissettiğinden ve pişmanlık duyduğundan bahsetmiştir. Ancak pişmanlık hissinin, ahlaki bir sorumluluk veya vicdani bir rahatsızlıktan mı; yoksa ilişki içinde bulunduğu kişilerin artık onunla ilgilenmemesi sonucu oluşan kullanılmışlık duygusundan mı kaynaklandığı açık değildir. Bu durumda tek cümlelik bir tavsiye ile değil, danışmanlık uygulamasının sonucu olarak "tövbe etme" kararı ortaya çıkmalıdır. Şöyle ki; öncelikle danışana duygu ve düşüncelerini ayırt edebilmesinde, inançlarını, fikirlerini vb. ifade etmesinde yardımcı olunmalı, danışanın varsayımlarını ve uygulamalarını gündeme getirerek düşünce ve davranışlarını sorgulaması sağlanmalıdır. Daha sonra uygun olduğu düşünüldüğünde, danışana düşünce örüntülerini değiştirmesinde destek olunmalıdır. Bir sonraki aşamada önceki süreçler değerlendirilerek, daha etkili biçimde sorunun nasıl çözüleceğinin; danışanın pişmanlık duygusundan arınmak için ne yapması gerektiğinin belirlenmesi noktasında ona yardım edilmelidir. Artık danışan tövbe etmeye kararlıysa, bunu nasıl yapacağına ve sonuçlarının dini boyutuna ilişkin bilgi verilmelidir. Son olarak, danışanın sağlıklı karar verme alışkanlığı geliştirmesinde ona yardımcı olunmalıdır. 
Burada başvuru sahibini yardım almaya yönlendiren şey, pişmanlık duygusuyla gelen bir huzursuzluk halidir. Dini danışmanın desteğiyle hatalı düşünce ve davranışını değiştirerek tövbe etmeye karar veren birey, bu eylemi gerçekleştirdikten sonra, sınırsız bir güce dayanmanın güveni içinde umut ve huzur duygusuna kavuşur. Böylece bu kişi, içtenlikle yaptığı tövbenin terapötik desteğiyle suçluluk duygusunun olası patolojik etkilerinden de korunmuş olur.

Aslında bu örnekle dini danışmanlık uygulamalarından, tek bir görüşmeyle değil sistemli bir danışmanlık serisi ile verim elde edilebileceği de anlaşılmaktadır. Çünkü bütün bunların tek seferlik bir görüşme ile sağlanması gerçekçi görünmemektedir. Danışanı tanıma ve neye gereksinim duyduğunu anlamakla başlayan danışmanlık süreci, danışanın problemin çözümünde gereken sorumluluğu üstlenmesini sağlamak ve onu desteklemek için oluşturulan diğer aşamaları takip ederek devam etmelidir. Yoksa arz edilen sorunu -danışanın içinde bulunduğu durumu nasıl algıladığına veya danışanın davranış ve düşüncelerinin gerisinde duran asıl problemin ne olabileceğine odaklanmadan- yanıtlanması gereken bir fetva sorusu gibi ele alarak değerlendirmek sağlıklı bir danışma ilişkisi oluşturmayacaktır.

\section{Büro Görevlilerinin Patolojik Düzeyde Sorunları Olan}

\section{Danışanlara Yaklaşımları:}

Üzerinde ciddiyetle durulması gereken diğer bir konu, patolojik düzeyde sorunları olan başvuru sahiplerine, büro görevlilerinin nasıl yaklaşması gerektiğidir. Zira bir kısım danışanın dini görünümlü sorusunun altında psikopatolojik problemler yatabilmektedir. $O$ halde, dini görünümlü kişisel ve psikososyal problemlerin çözümüne yardımcı olunurken, bunların bireyin başka problemleri ile de bağlantılı olarak ortaya çıkabileceği göz önüne alınmalı ve problemin çeşitli komplikasyonları da görülebilmelidir. Aksi halde soru, sadece dini fetva eksenli görülüp değerlendirilecektir. Bu durumda problemin çözümüne yardımcı olabilmek için katkı sağlamak bir yana, mevcut sorun daha karmaşık hale getirilebilir (Karacoşkun, 2007). Dolayısıyla büro görevlilerinin sistemli ve bilimsel bir altyapıyla, sergilemesi gereken doğru 
Aile ve Dini Rehberlik Bürosu Görevlilerinin Karşılaştıkları Psikososyal Sorunlara Yaklaşımlarının Dini Danışmanlık ve Rehberlik Açısından Değerlendirilmesi | 679

tutumu belirleyebilecek ve gerekiyorsa ilgili birime yönlendirebilecek kadar donanımlı olması gerekir. İçinde dini yüksek okul mezunu olup farklı alanlarda hizmet veren din görevlilerinin de olduğu büro personelinin, psikolojik ve teolojik altyapısı olan akademik eğitim almış olması, kompleks yapıda olan sorunları doğru bir yaklaşımla ele almayı sağlarken gerekli ve yeterli düzeyde bilgi ve beceriden yoksun olmak bu durumu zorlaştıracaktır.

Konuyla ilişkili olarak yapılan bir çalışmada din görevlilerinin, şizofreninin etyolojisi ve tedavisi ile ilgili bilgilerinin ve şizofreniye ilişkin tutumlarının tespit edilmesi amaçlanmıştır (Eker, Öner ve Şahin, 2010). Çalışma sonuçları bütün din görevlileri için geçerli olmasa da belirleyici bir yönü olması nedeniyle düşündürücüdür. Bu çalışmaya göre, din görevlilerinin \%85'i şizofreniyi bir ruhsal zayıflık hali olarak görürken, yarıya yakını (\%46.4) şizofreniyi aşırı üzüntü hali olarak değerlendirmiştir. Ayrıca \%33.3'ü şizofreni hastalarının serbestçe dolaşmamaları gerektiğini, \%41.9'u şizofreni olan bir komşudan rahatsızlık duyacağını, \%37.1'i şizofreni hastalarının saldırgan olacağını belirtmişlerdir. Araştırma sonucunda toplum önderleri olan din görevlilerinin; şizofreninin etyolojisini, tedavisini, şizofren hastaların damgalanmasının tedavi üzerindeki etkilerini ve damgalanmanın önlenmesi için din görevlilerinin üstlenmesi gereken rol ve sorumlulukları içeren bir eğitime intiyaçları olduğu görülmüştür.

Bir şizofreni hastası, "ilaç kullanıyorum. Bazı zamanlarda kontrolüm dışında Peygamber Efendimize küfrediyorum. Bu durum beni üzüyor. Dinden çıkacağım diye endişeleniyorum. Ne yapmam lazım?" sorusuyla başvuruda bulunmuştur. Sadece böyle bir soruyla karşılaşmak bile, söz konusu eğitimin önemine işaret etmektedir.

Şizofreni gibi düşünce, duygu ve davranış alanında herkes tarafından gözlenebilen önemli bozulmaların ortaya çıktığı ruhsal rahatsızlıkları olan bireyler, toplumca tanınabilirken; sağlıksız bazı kişilik görünümlerinin tanınması oldukça zordur. Hatta bazı kişilik bozuklukları, ideolojik, siyasi, dini ve bilimsel kisvelere bürünebilmektedir. Zaman zaman medya aracılığıyla tanık 
olduğumuz mehdilik iddiasında bulunan ve çevresini dahi etkileyebilen bireyler buna örnek gösterilebilir. Onları böyle bir iddiada bulunmaya iten şey, seçilmişlik duygusudur. Seçilmişlik duygusu mehdilik iddiasında bulunmaya götürmese bile, özellikle narsistik ve paranoid kişilik bozukluğu olan bireylerin hastalıklı bir bakış açısına sahip olmasına neden olur (Göka, 2012).

Bürolara gelen sorular analiz edildiğinde; şizofreni gibi psikotik bozukluğu, bipolar bozukluk ve depresyon gibi duygudurum bozukluğu veya daha sıklıkla obsesif kompulsif bozukluğu olan bireylerin, dini içerikli sorularıyla başvuruda bulunduğu anlaşılmaktadır. Dolayısıyla, psikiyatri ve psikoloji bilimleri açısından ele alınması gereken bazı vakalarda, büro görevlilerinin kullanacağı bir kelime ya da yaklaşımın, danışanın ruhsal durumu üzerinde olumlu veya olumsuz anlamda ciddi etkiler meydana getirebileceği hesaba katılmalıdır (DiB, 2009, 10).

\section{Büro Görevlilerinin Aile ve Evlilik IIlişkileriyle IIIgili Sorunları Olan Danışanlara Yaklaşımı:}

Aile ve Dini Rehberlik Bürolarına, aile ve evlilik danışmanlığını gerektiren başvurular da olmaktadır. Danışanların daha çok aile içi statülere ait rol karışıkığı, ailede anne-babadan birinin yokluğu, yanlış adet, gelenek ve alışkanlıklar, dine mal edilen anlayış ve tutumlar, sorunlu çocuklar, evlilikte yaşanan uyum güçlükleri (Cebeci, 2012, 175-181) gibi karakteristik aile sorunlarıyla geldiği görülmektedir. Danışanlar her zamanki gibi, sorunlarını inandıkları dinin belirlediği sınırlar içerisinde çözmek istemekte ve müftülükler bünyesinde bulunan aile bürolarına müracaat etmektedirler.

Otuz yıldır kayınvalidesi ile beraber yaşayan ve yatalak kayınvalidesine bakan bir bayan, başka bir ildeki kardeşinin düğününe katılmak istediğini, kayınvalidesinin iki çocuğu daha olmasına rağmen, kocasının gitmesine izin vermediğini söyleyerek derdini paylaşmıştır. Büro görevlisi ise bu danışana, mükafatını Cenab-ı Hak'tan bekleyerek kocasının sözünü dinlemesini tavsiye etmiştir (DiB, 2009, 9). 
Aile ve Dini Rehberlik Bürosu Görevlilerinin Karşılaştıkları Psikososyal Sorunlara Yaklaşımlarının Dini Danışmanlık ve Rehberlik Açısından Değerlendirilmesi | 681

Başka bir kadın danışan, eşine dinin emir ve yasaklarını hatırlattığında şiddet gördüğünü dile getirmiş, büro görevlisi de hanımların kocalarına, emr-i bi'l maruf yapmakla sorumlu olmadığını dile getirerek eşine bu konuda tekrar tekrar hatırlatma yaparak boşuna dayak yememesi önerisinde bulunmuştur (DiB, 2009, 9).

Yine bir kadın danışan eşiyle yaşadığı sorunu şöyle dile getirmektedir: "16 yıllık evliyim. Eşim sürekli bana hakaret ediyor ve beni aşağılıyor. Abilerimin yanında çalıştığı için onlarla olan sorunlarını bana yansıtıyor. Nasıl davranmam gerekir?” Büro görevlisi ise, "eşiniz muhtemelen abilerinize söyleyemediklerinin hıncını sizden çıkarıyor. Üzerinde bir baskı hissediyor olabilir. Bu yüzden sizinle olan ilişkisini dengeleyemeyebilir. Eşinizin başka bir iş bulma imkanlarını birlikte konuşarak değerlendirin. Ya da eşinizin haklı olduğu durumlarda abilerinizin yanında değil, eşinizin yanında yer almaya ve ona olan güveninizi hissettirmeye çalışın. Aranızdaki ilişkiler daha fazla yıpranmadan karşılıklı konuşarak stres nedenlerini çözmeye çalışın.” şeklinde cevap vermektedir.

Son örnekte danışan problemini telefonda dile getirmiştir. Bunun, yardım ilişkisinde olumsuz bir etki oluşturabileceğini daha önce belirtmiştik. Özellikle telefonla yapılan görüşmelerde "sorulan soruyu yanıtlama" noktasından hareket edilmekte, bu da sağlıksız bir danışmanlık ilişkisinin başlangıcını oluşturmaktadır. Bu yüzden eğer görüşme telefonla başlamışsa bunun ardından yüz yüze bir görüşme planlanmalıdır.

Verdiğimiz örneklerle, yapılan tavsiyelerin doğruluk veya yanlışlığından çok, kullanılan üslupla ve tavsiyelerin sorunun güçlüğü karşısında yüzeysel kalmasıyla ilgili hataların olduğuna vurgu yapmak istiyoruz. Zaman zaman danışanlar, dini otorite olarak gördükleri büro görevlisinden tavsiye isteyebilmektedirler. Ancak yüzeysel bir yaklaşım olan tavsiye, danışmada sıklıkla kullanılmamalıdır. Çünkü bireyi, sorunun derinliğine inerek içgörü geliştirmeye yöneltmeyip, karşılaştığı bir darboğazdan daha kestirmeden çıkarmayı sağlar (Tan, 1992, 169). Diğer taraftan bu uygulamalar, aile ve evlilik danışmanlığı perspektifinden incelenmeyi gerektiren bir yapıdadır. Aile ve 
evlilik danışmanlığı ise bireyi, içinde bulunduğu sistemin bir parçası olarak değerlendiren bir terapi sürecidir. Bu nedenle problem hakkında, kişi ya da kişiler hakkında yeterli bilgi almadan açıklama yapmaya çalışmak doğru değildir.

Öncelikle aile içindeki bireyin bağlılık durumunu, öteki aile bireyleriyle etkileşimini, bulunduğu sistem içindeki konumunu ve ailesel ilişki örüntülerinde bunun ne şekilde yer aldığını bilmek; evli çiftlerin, ailenin ya da daha geniş ölçekli sistemlerin yaşadığı sorunun tespiti ve çözümü noktasında belirleyici olmaktadır. Danışanın veya yakınının sorunlu olarak algılanan hareketi ailenin işlevine karşı geliştirilmiş bir davranış olabileceği gibi, sorunlu davranış aile sürecini işletiyor veya aile üyelerinin dengeli bir etkileşimde bulunmayışının sonucunda ortaya çıkıyor olabilir. Ya da kuşaktan kuşağa aktarılmış bir işlev bozukluğu örüntüsü olabilir (Corey, 2008, 457). Bunu anlayabilmek için profesyonel bir yaklaşımla -tek bir bireyin aktarımını değil- ailenin dokusunu, bütünlüğünü, kurallarını ve iletişim anlayışını incelemek gerekir.

Psikolojik danışmanlıkta ayrı bir uzmanlık dalı olan, aile ve evlilik danışmanlığı bu çalışmanın içinde ayrıca yer almadığından; aile ve evlilik terapisi kuramları, ailede ve evlilikte işlev bozuklukları, aile ve evlilik terapisi teknikleri gibi temel konularla bağlantılı olarak, bürolarda aile ve evlilik danışmanlığının nasıl yürütülmesi gerektiğiyle ilgili özgün bir çalışmanın yapılmasının faydalı olacağı kanaatindeyiz.

\section{Büro Görevlilerinin Dini Danışmanlık Dışında Kalan Psikolojik Yardım Mesleklerinin Desteğini Gerektiren Sorunlara Yaklaşımı:}

Son olarak ele almak istediğimiz konu büro görevlilerinin gerektiğinde, danışanları diğer kurum ve kuruluşlara yönlendirmesiyle ilgilidir. Bazı durumlarda danışmanlık hizmeti veren büro görevlisinin kendi alanı dışındaki uzmanlık gerektiren konularda hüküm/teşhiste bulunduğu görülmektedir. Üç yaşındaki çocuğunun aksiliklerinden söz eden bir kadın danışana büro görevlisinin, "bu hali ilk ergenlik bunalımından ileri geliyor" demesi veya başka bir büro görevlisinin, babasının ahlaki problemlerinden dert yanan bir kadın 
Aile ve Dini Rehberlik Bürosu Görevlilerinin Karşılaştıkları Psikososyal Sorunlara Yaklaşımlarının Dini Danışmanlık ve Rehberlik Açısından Değerlendirilmesi | 683

danışana, "babanız andropoz dönemindedir" şeklinde açıklamada bulunması buna örnek gösterilebilir (DİB, 2009, 9).

Bununla birlikte, Başkanlığın bu konuda titiz davranıp büro görevlilerinin yetersiz yönlendirme yaptığına dair uyarılarda bulunduğunu belirtmek yerinde olacaktır. Ancak biz bu yönlendirmenin tek taraflı değil karşılıklı olması gerektiğinin özellikle altını çizmek istiyoruz.

Bir danışan, çeşitli sıkıntılarından söz ederken çocuklarının bakım ihtiyacını çevreden gelen yardımlarla karşıladığından bahsediyor. Bu bireyin maddi zorlukları aşması ve eğer çalışarak kazanmaya gücü varsa uygun bir işte görev alması, çocuklarının -ihtiyaç duyuyorlarsa- rehabilitasyonlarının sağlanması, diğer aile bireylerinin içinde bulunduğu durum araştırılarak gereken yardımın yapılması ancak bir sosyal hizmet uzmanı/sosyal çalışmacının desteğiyle mümkün olabilir.

Diğer bir örnekte danışan, obsesif kompulsif bozukluğu olduğundan ve neyin günah olup neyin olmadığını kafasına çok taktığından bahsediyor. Bu örnekte psikiyatrik yardıma gereksinim duyan danışan, inandığı dinin gerekleriyle ilişki kurarak davranışlarına yön vermek istemektedir. $\mathrm{Bu}$ ise psikiyatr ve dini danışmanın karşılıklı işbirliği ve yönlendirme yaparak çalışmasını gerektirir.

Karşılıklı işbirliği ve yönlendirme ancak, bürolarda görev alan dini danışmanların yeterli eğitim ve deneyimi kazanmış, mesleki kimlikleri gelişmiş, gerektiğinde bir üst aşamaya geçişi veya önceki aşamaya dönüşü sağlayarak (Altaş, 2012, 27) yardım meslekleriyle koordineli çalışabilen uzmanlardan oluşmasıyla gerçekleşebilir.

\section{Sonuç}

Diyanet İşleri Başkanlığına bağlı bulunan Aile ve Dini Rehberlik Bürolarında gerçekleşen dini danışmanlık ve rehberlik uygulamalarının incelendiği bu araştırmada danışanların bürolara getirdiği sorunların içeriği ve 
büro görevlilerinin bu sorunlara yaklaşımlarının nasıl olduğu analiz edilmeye çalışılmıştır. Sonuçta;

1. Aile ve Dini Rehberlik Bürolarına başvuran danışanların, bir konunun dini hükmünü bilmek istedikleri için yardım isteğinde bulundukları ancak, çoğu kez psikolojik ve sosyal problemlerini de üstü kapalı veya açık olarak dile getirdikleri tespit edilmiştir. Yaşanan bu problemlerin ise mutsuzluk, çaresizlik, kararsızlık, suçluluk, değersizlik, bitkinlik, sosyal ortamlardan kaçınma gibi çeşitli yansımalarının olduğu görülmüştür.

2. Araştırma bulguları doğrultusunda, Aile ve Dini Rehberlik Bürosu görevlilerinin gerçekleştirdikleri görüşmelerde, danışanın diğer psikososyal dinamikleri de içeren dini sorusunu bir fetva sorusu gibi ele alıp değerlendirdikleri ve dolayısıyla gereksinimlere cevap veren bir danışma oluşumu sağlamada işlevsel olamadıkları kanaatine ulaşıımıştır. Yapılan görüşmeleri ele aldığımızda bu kanaate ulaşmamızda etkili olan unsurları şöyle sıralayabiliriz: Büro görevlilerinin doğru bir danışmanlık ilişkisi için gereken koşulları sağlamada ve danışmanlık becerilerini sergilemede yetersiz kalabilmeleri, danışanların sorunlarını içgörü kazanarak ve etkin kararlar alarak çözmelerini sağlamada eksik rehberlik yapmaları, patolojik düzeyde sorunları olan danışanlarla kurulacak yardım ilişkisinde sistemli ve bilimsel bir altyapıya sahip olma konusunda yetersiz olmaları, danışanların aile ve evlilik ilişkileriyle ilgili sorunlarını çözme noktasında gereken donanıma sahip olmamaları, diğer yardım meslekleriyle işbirliği ve yönlendirme ekseninde koordineli çalışabilecek eğitim ve deneyime sahip olmamaları.

3. Diyanet İşleri Başkanlığının bu bürolarda görevli personelin yetiştirilmesi ve daha verimli hizmet sunulabilmesi amacıyla organize ettiği eğitim programlarının görevlilerin; danışanların sorunlarıyla ilgili farklı boyutları görebilme ve onları daha iyi anlama, danışma oluşumundaki şartları tanıma ve danışma sürecini doğru yönetebilme, danışmanlıkta kullanılabilecek bazı terapötik tekniklerden yararlanabilme gibi kazanımlar elde etmesini sağlayabilecek kapsamda olmadığı anlaşılmıştır. 
4. Aile ve Dini rehberlik Bürolarında görevlendirilen personelin sadece yüz yüze değil telefonla da danışmanlık hizmeti vermeye çalıştığı belirlenmiştir. Ancak bazen büro görevlisine yöneltilen soru tek başına bir fetva sorusu olmayıp dini ve psikososyal boyutlarıyla karmaşık hale gelmiş komplike bir sorun olabilmektedir. Böyle durumlarda telefonla başlanıp bitirilen bir görüşmenin danışma etkileşimini sağlamada yeterli olamadığı sonucu araştırma bulguları ışığında ortaya çıkmıştır.

\section{Öneriler}

1. Aile ve Dini Rehberlik Bürolarında istihdam edilmek üzere, dini bilimlerin dışında temel danışmanlık bilgi ve süreçlerinden psikoterapi teknikleri ve aile danışmanlığına kadar seküler bilimlerde de yeterli donanımı olan dini danışmanların yetiştirilmesi için lisans ve lisansüstü eğitim programlarının oluşturulmasının ve buralarda yetişen dini danışmanların bu bürolarda görevlendirilmesinin, söz konusu hizmetin profesyonelleşmesi adına yararlı olacağı kanaatindeyiz.

2. Bu çalışmada Aile ve Dini Rehberlik Bürolarında yürütülen dini danışmanlık hizmetlerini mercek altına alarak, bu bürolar bazında ülkemizde anlaşılan ve uygulanan dini danışmanlığın ne olduğunu araştırmaya çalıştık ve sonuçta düzenli ve ilkeli bir danışmanlık hizmeti verilmediğini gösteren bazı bulgulara ulaştık. Bu bağlamda, gerçekte bir uzmanlık dalı olan dini danışmanlığın nasıl uygulanması gerektiğini belirlemek ve hatta metodolojisi ve kendine has stratejik yöntemleri olan bir disiplin olarak gelişmesini sağlamak amacıyla yeni akademik çalışmaların yapılmasına intiyaç olduğunu düşünmekteyiz.

3. Mevcut durumda Aile ve Dini Rehberlik Bürolarında verilen dini danışmanlık hizmeti artık fetva hizmetiyle aynı mekanizma içinde yürütülmemektedir. Ancak uzunca bir zaman fetva hattında kullanılagelen telefonda soru cevaplama yöntemi, Aile ve Dini Rehberlik Bürolarında halen kullanılmakta ve bazı görüşmelerin telefonda yapılmasına devam edilmektedir. $\mathrm{Bu}$ da verimli bir danışmanlık hizmeti sunabilmenin önündeki en büyük 
engellerdendir. Bizce olması gereken, telefonun sadece randevu vermek için kullanılması, görüşmelerin ise yüz yüze yapılmasıdır.

4. Aile ve Dini Rehberlik Bürolarının genellikle müftülük binasında bulunduğu gözlenmektedir. Dini danışmanlık hizmetinin verildiği bu mekanlarda ayrı bir görüşme odası olsa bile, bu odaların fiziksel açıdan ideal danışma ortamını tam olarak karşılamadığı bilinmektedir. Bir dini danışman otorite figürü olarak çalışma masasının arka tarafında bulunmamalı, danışanla arasında duyguların iletimini engelleyen bir yerleşim düzeni olmamalıdır. Bu açıdan büroların, görüşme odası ile oturma düzenini oluşturan mevcut fiziksel koşulların yeniden düzenlenmesi ve resmi devlet binası olan müftülük dışındaki sivil yapılarda konumlandırılması gibi çalışmalarla standardizasyonunun sağlanmasının faydalı olacağı kanaatindeyiz.

\section{Kaynakça}

Altaş, N. (2000). Dini danışmanlığın teorik temelleri. Ankara Üniversitesi Illahiyat Fakültesi Dergisi, 41, 327-350.

Altaş, N. (2012). Din hizmetleri ve dini danışmanlık ilişkisi. Nurullah Altaş ve Mustafa Köylü (Ed.). Dini Danışmanlık ve Din Hizmetleri içinde (s. 1135). Ankara: Günüz Yayınları.

Aşıkoğlu, N. Y. (2012). Yüksek Öğretimde Din Eğitim ve Öğretimi. Recai Doğan ve Remziye Ege (Ed.). Din Eğitimi El Kitabı içinde (s. 215-228). Ankara: Grafiker Yayınları.

Cebeci, S. (2010). Bir din öğretimi yaklaşımı olarak dini danışma ve rehberlik. Değerler Eğitimi Dergisi, 8(19),53-69.

Cebeci, S. (2012). Dini Danışma ve Rehberlik. Ankara: Aydoğdu Ofset.

Corey, G. (2008). Psikolojik Danışma, Psikoterapi Kuram ve Uygulamaları. (Çev. T. Ergene). Ankara: Mentis Yayıncılık. (Eserin orijinali 2005 yılında yayımlandı).

DỉB, (2009). Aile Irşat ve Rehberlik Bürosu Görevlileri İçin Notlar (1122 Mayıs 2009 Aile Irşat ve Rehberlik Bürosu Görevlileri Semineri). Din Hizmetleri Dairesi Başkanlığı İrşat Hizmetleri Şubesi Müdürlüğü. Diyanet İşleri Başkanlığı: Ankara.

DiB, (2015a). Diyanet İşleri Başkanlığı: Ankara. 
Aile ve Dini Rehberlik Bürosu Görevlilerinin Karşılaştıkları Psikososyal Sorunlara Yaklaşımlarının Dini Danışmanlık ve Rehberlik Açısından Değerlendirilmesi | 687

http://www2.diyanet.gov.tr/DinHizmetleriGenelMudurlugu/Sayfalar/Gor evler.aspx erişim tarihi: 07.10.2015

Dỉ, (2015b). Diyanet İşleri Başkanlığı: Ankara.

http://www2.diyanet.gov.tr/DinHizmetleriGenelMudurlugu/Sayfalar/lsbi rligiProtokolleri.aspx erişim tarihi: 08.10.2015

Ege, R. (2011). "Dini danışmanlık ve rehberlik" in bir bilim dalı olarak gelişmesinin gerekliliği üzerine bazı düşünceler. Dini Araştırmalar Dergisi, 14(39), 104-114.

Ege, R. (2015). Dini Rehberlik. İstanbul: Şule Yayınları.

Ergül, H. (2008). "Müzakere (problem çözme) ve arabuluculuk" eğitim programının ortaöğretim 9. Sınıf öğrencilerinin çatışma çözüm becerileri ile saldırganlık düzeyleri üzerindeki etkisinin incelenmesi. Yayımlanmamış yüksek lisans tezi. Dokuz Eylül Üniversitesi Eğitim Bilimleri Enstitüsü, İzmir.

Eker, F., Öner, Ö. ve Şahin, S. (2010). Din görevlilerinin şizofreniye iliş̧in bilgi ve tutumları (Düzce örneği). Psikiyatri Hemşireliği Dergisi, 1(2), 6370.

Göka, E. (2012). Mehdilik iddiası ve psikopatoloji. http://www.aktuelpsikoloji.com/artikel.php?artikel id=1412 erişim tarihi:30.12.2014

Hackney, H., Cormier,S. (2008). Psikolojik Danışma Ilke ve Teknikleri: Psikolojik Yardım Süreci El Kitabı. (Çev. T. Ergene ve S. Aydemir Sevim). Ankara: Mentis Yayınclık. (Eserin orijinali 2005 yılında yayımlandı).

Karacoşkun, M.D. (3-4 Kasım 2007). Din görevlilerinin bireylerin dini görünüşlü kişisel ve sosyopsikolojik problemlerine katkı sağlayabilme yolları. I. Din Hizmetleri Sempozyumunda sunulmuş bildiri, Ankara.

Karagül, A. (24 Mayıs 2012). Manevi bakım ve Hollanda örneği. I. Ulusal Din Psikolojisi ve Manevi Bakım Çalıştayında sunulmuş bildiri, Ankara.

Koç, M. (2014). Manevi-(Psikolojik) Danışmanlık Müslüman Türk Diasporası Örneği. Bursa: Emin Yayınları.

Ok, Ü. (2012). Dini danışmanlık: tanımı ve tarihi. Nurullah Altaş ve Mustafa Köylü (Ed.). Dini Danışmanlık ve Din Hizmetleri içinde (s. 38-58). Ankara: Günüz Yayınları.

Özdemir, Ş. (2007). Müftülerin Gözüyle Din Hizmetleri. İstanbul: Değerler Eğitimi Merkezi Yayınları.

ÇÜiFD, 2018, cilt: 18, sayı: 2, ss. 661-689 
Peker, H. (2012). Aile İrşat ve Rehberlik Bürolarında dini danışmanlık ve din hizmetleri. Nurullah Altaş ve Mustafa Köylü (Ed.). Dini Danışmanlık ve Din Hizmetleri içinde (s. 341-356). Ankara: Günüz Yayınları.

Sayar, K. (2014). Terapi. (5. Baskı). İstanbul: Timaş Yayınları.

Söylev, Ö. F. (2015). Psikolojik yardım hizmetleri bağlamında Türkiye'de dini danışma ve rehberlik. İslam Medeniyeti Araştırmaları Dergisi, 1(2), 78-99.

Şirin, T. (2014). Dini danışma ve Rehberlik. İstanbul: Erkam Matbaası.

Tan, H. (1992). Psikolojik Yardım İlişkileri. İstanbul: MEB yayınları.

Tümer, G. (1994). Genel Olarak Din. Türkiye Diyanet Vakfı İslam Ansiklopedisi (Cilt 9). İstanbul: DiVANTAŞ.

Voltan Acar, N. (2012). Birey Merkezli Grupla Psikolojik Danışma Süpervizyonlu Oturum Örnekleri. Ankara: Nobel Yayınları.

Voltan Acar, N. (2014). Yeniden Terapötik IIletişim Kişiler Arası İlişkiler (Tamamı Bizim Toplumdan Örnekler). (10. Baskı). Ankara: Nobel Yayıncılık. 


\title{
An Evaluation of Psychosocial Problems Faced by Employees in Family and Religious Guidance Bureau According to Pastoral Counseling and Guidance Terms
}

Citation / (-- Angın, Y. ve Altaş, N. (2018). An Evaluation of Psychosocial Problems Faced by Employees in Family and Religious Guidance Bureau According to Pastoral Counseling and Guidance Terms, Cukurova University Journal of Faculty of Divinity, 18 (2), 661-689.

\begin{abstract}
This study investigates the content of the services provided by the Family and Religious Guidance Bureau of Presidency of Religious Affairs according to pastoral counseling and guidance terms. For this aim, the consultancy services offered at this office were evaluated in respect of pastoral counseling and guidance terms. Document analysis method was used in this study. The research population consists of clients who consult and consultants who work in the Family and Religious Guidance Bureau across Turkey. The samples were determined by purposeful sampling method among the office staff, whose speeches/answers were reflected to written documents, and the clients requesting the interview. The sources of data used in this study were obtained from the literature and the questions asked, 6857 cards, to the Family and Religious Guidance Offices throughout the country in the first 10 months of 2014. The obtained data were analyzed according to the content and categorized according to the sub-objectives of the study. In this context, some of the approaches to clients of counseling practices were scrutinized and evaluated in terms of counseling desk attendant principles. Results obtained from this study have shown that the clients who consult to the Family and Religious Guidance Bureau are mainly searching for help because they want to know the religious judgment of the subject they asked; however, it is observed that they sometimes expressed their psychological and social problems explicitly or implicitly. These problems are seen to have various manifestations such as unhappiness, helplessness, indecision, guilt, worthlessness, exhaustion, avoidance from the social environment. Results obtained have also indicated that office staff are inadequate to give the scientific and systematic infrastructure required for an ideal consultation process. These findings can be listed as; the lack of adequate training to provide the necessary conditions for an accurate counseling relationship and inability to demonstrate counseling skills, making insufficient counselling by not gaining insight and taking effective decisions, not having the necessary education to solve the problems of pathologically challenged clients and problems of family and marriage, and the lack of training and experience that can be coordinated with the cooperation and guidance of other professions.
\end{abstract}

Keywords- Family and Religious Guidance Bureau, religious counseling and guidance, psychosocial issues 